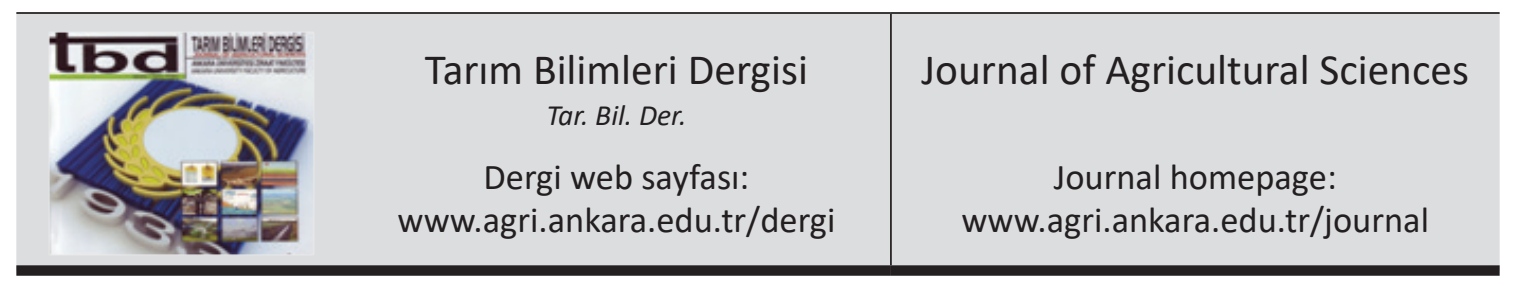

\title{
Comparisons of Physical and Chemical Characteristics of Eggs Obtained using Hens Reared in Deep Litter and Free-Range Systems
}

\author{
İsmail TÜRKER ${ }^{\mathrm{a}}$, Sezai ALKAN ${ }^{\mathrm{b}}$ \\ ${ }^{\boldsymbol{a}}$ Yozgat Bozok University, Faculty of Agriculture, Department of Animal Science, Yozgat, TURKEY \\ ${ }^{\boldsymbol{b}}$ Ordu University, Faculty of Agriculture, Department of Animal Science, Ordu, TURKEY
}

\section{ARTICLE INFO}

Research Article

DOI: 10.15832/ankutbd.378578

Corresponding Author: İsmail TÜRKER, E-mail: iturker37@hotmail.com, Tel: +90 (354) 2421028

Received: 13 January 2018, Received in Revised Form: 21 March 2018, Accepted: 04 April 2018

\begin{abstract}
This study was designed to compare the physical and chemical qualities of eggs obtained using hens reared in free-range and deep-litter systems. A total of 300 Lohmann Brown hens (150 for each housing system) were used. In the free-range system, $4 \mathrm{~m}^{2}$ grazing area was allocated for each hen. The hens were taken into layer house at 16 weeks of age. Hen egg production reached up to $50 \%$, produced eggs were randomly sampled once every 4 weeks until 52 weeks of age and physical characteristics of eggs from each housing system were measured. Results revealed that there was no significant difference in egg shell color, egg weight, breaking strength, shell thickness, shape index, specific gravity, yolk color, albumen index, haugh unit, meat and blood spots of eggs from two housing systems. However, there was a significant difference in yolk index. It was determined that housing systems effected the chemical content of the egg and the eggs obtained from free-range system were significantly richer in essential amino acids, vitamin $\mathrm{D}_{3}$ and biotin.
\end{abstract}

Keywords: Hens; Free-range system; Deep-litter systems; Egg quality

(C) Ankara Üniversitesi Ziraat Fakültesi

\section{Introduction}

One of the biggest challenges of human beings in today's world is to maintain healthy diet, which is strongly associated with life quality. A key component of maintaining the healthy diet is to consume adequate and balanced amount of animaland plant-based products. One of the excellent source of animal-based proteins is egg. This is because egg proteins are highly digestible (98\%), high in biological value (94\%), and rich in essential amino acids (Altan 2015).

After the consideration of animal rights in egg production systems has started to gain importance, different alternative housing systems with a consciousness of food safety were developed in order to produce high quality eggs. This goes along with consumers' demands that they prefer to consume eggs produced using such systems (Anderson 2009).

The genotype of the hens (Hanusová et al 2015) and the housing systems used in production (Doley et al 2010; Nistor et al 2014; Angelovicova et al 2014; Yang et al 2014; Nistor et al 2015) significantly affect the egg quality. It has been observed that different hen genotypes used in production react differently to different housing systems (Leyendecker et al 2001). 
However, in various studies, findings support the fact that eggs produced from hens reared in free-range system are higher in quality (Krawczyk \& Calik 2006; Senčic et al 2006; Krawczyk \& Gornowicz 2010; Yang et al 2014; Nistor et al 2014), compared to other systems. This is mainly attributed to the fact that hens reared in free-range system are exposed to direct sunlight, have plenty of space for movement, and they can access to green grass and different food resources in open space.

Since alternative production systems are important in terms of both variation and animal welfare in egg production, it is required to study and put forward the effects of these production systems on productivity and quality of eggs in detail. Although various studies exist on this manner, they are not adequate to piece together in order to discover the best system for the production of eggs with high quality. In this study, it is aimed to determine the physical and chemical qualities of eggs obtained from hens reared in deep litter and free-range systems and pointing out the differences between both housing systems.

\section{Material and Methods}

In the study, a total of 300 hens consisting of 150 Lohmann Brown hybrids in each of deep-litter and free-range system groups were used. The study was carried out with a research henhouse in the city of Ordu, which is located in the Black Sea Coast of Turkey. In the free-range system, out of the henhouse, a green area of $4 \mathrm{~m}^{2}$ was allocated for each hen. Five hens were placed in each meter square into henhouse. Chicks were transferred following hatchery to an environmentally controlled growth house and were exposed to $10 \mathrm{~h}$ daily lighting until the age of 16 weeks. The hens were placed in henhouse with windows at 16 weeks of age. After the 18 weeks of ages, the lighting period was increased for 1 hour periodically in every week until the daily lighting reached $16 \mathrm{~h}$. Once it reached $16 \mathrm{~h}$, no more increase was made in the daily lighting and it was stabilized at $16 \mathrm{~h}$. Water and feed were provided add libitum in both rearing systems throughout the experiment. The hens were fed with 1. period layer diets according to NRC (1994).

\subsection{The physical quality characteristics of the egg}

The physical characteristics were determined in eggs once every 4 weeks from onwards $50 \%$ production age of hens, and totally 160 eggs were used in each group. For this purpose, the eggs were brought into the laboratory and kept at room temperature for 24 hours. Afterwards, the following characteristics were determined.

\subsubsection{Egg weight}

It was determined by weighting with a scale at 0.01 g sensitivity.

\subsubsection{Shape index}

It was determined by using a digital caliper to measure width and height of the egg.

\subsubsection{Specific gravity $\left(\mathrm{g} \mathrm{cm}^{-3}\right)$}

It was calculated with Equation 1.

Specific gravity $\left(\mathrm{g} \mathrm{cm}^{-3}\right)$ : Weight in air $(\mathrm{g}) /$

Weight in air (g) - Weight in pure water $(\mathrm{g})$

\subsubsection{Shell breaking strength}

It was determined by using a shell breaking strength measurement tool in $\left(\mathrm{kg} \mathrm{cm}^{-2}\right)$.

\subsubsection{Shell color}

It was determined by using the shell color scale developed by Hy-Line Company.

\subsubsection{Eggshell thickness}

It was measured in $\mathrm{mm}$ by using a micrometer.

\subsubsection{Albumen index}

It was calculated with Equation 2.

Albumen index: Height of albumen ( $\mathrm{mm}) /$ Average of length and width of albumen $(\mathrm{mm}) * 100$

\subsubsection{Yolk index}

It was calculated with Equation 3.

Yolk Index: Egg yolk height (mm) / Egg

yolk diameter $(\mathrm{mm}) * 100$ 


\subsubsection{Haugh unit}

It was calculated with Equation 4.

Haugh unit: $100 \log \left(\mathrm{H}+7.57-1.7 \mathrm{G}^{0.37}\right)$

(Haugh 1937).

Where; $\mathrm{H}$, albumen height (mm); G, egg weight (g)

\subsubsection{Meat and blood spots}

Eggs having meat and blood spots were counted and expressed as $\%$.

\subsubsection{Yolk color}

It was determined by Roche color scale with 15 yellow color shades.

\subsection{Chemical quality characteristics}

The chemical analyses of the eggs were done in Food Institute Laboratory of Marmara Research Center. For this purpose, a total of 120 eggs, with 60 eggs from each group were used. The tested eggs were obtained from hens which are 52 weeks old. The chemical analyses targeted in this study were total energy (Atwater method), A, E, B $, \mathrm{B}_{2}, \mathrm{~B}_{6}$ folic acid, niacin, $\mathrm{B}_{5}, \mathrm{~B}_{7}, \mathrm{~K}_{2}, \mathrm{D}_{3}, \mathrm{~B}_{12}$ vitamins (HPLCFLD method), alanine, aspartic acid, glutamic acid, serine, glycine, histidine, arginine, threonine, proline, tyrosine, valine, methionine, leucine, isoleucine, phenylalanine and lysine amino acids (UFLC-UV method), omega-3 and omega-6 oil acids (IUPAC IID 19 method), selenium and cholesterol analyses (Chromatography method) were done.

\subsection{Statistical analysis}

For all traits taken into account in the study, the control of normal distribution was done by using
Kolmogorov-Smirnov test. The effects of group, time (linear, quadratic and cubic), and interaction on the internal and external egg quality characteristics were analyzed with MIXED procedure of the SAS software. While the time effects were significant for all mentioned characteristics, the age*group interaction effects were found to be statistically insignificant. For this reason, the time effect was removed from the model, and only the groups were compared for all traits. T-test was used in the evaluation of the traits which fulfill the assumptions. Nonparametric data were analyzed by MannWhitney test. For the data expressed as rates and $\%$, angle transformation was carried out. Data were analyzed with Minitab 16 software (Anonymous 2010).

\section{Results and Discussion}

Research findings relating external quality characteristics have been presented in Table 1, and those concerning internal quality characteristics are presented in Table 2. It was found that there is not a difference between housing systems in terms of the researched characteristics of egg shell color, weight, breaking strength, shell thickness, shape index, specific gravity, yolk color, albumen index, haugh unit, meat and blood spot proportion $(\mathrm{P}>0.05)$. On the other hand, it was found that there is a significant difference in terms of yolk index between the systems $(\mathrm{P}<0.05)$. The yolk index of eggs obtained from hens reared in free-range system was found to be higher than those reared in deep litter system.

Chemical analysis results of the eggs produced through free-range and deep litter systems are given in Table 3. Differences occurred in the food

Table 1- External quality characteristics of eggs

\begin{tabular}{lccccccc}
\hline \multirow{2}{*}{ Groups } & & $\begin{array}{c}\text { Shell } \\
\text { color }\end{array}$ & $\begin{array}{c}\text { Egg weight } \\
(\mathrm{g})\end{array}$ & $\begin{array}{c}\text { Breaking strength } \\
\left(\mathrm{kg} \mathrm{cm}^{-2}\right)\end{array}$ & $\begin{array}{c}\text { Shell thickness } \\
(\mathrm{mm})\end{array}$ & $\begin{array}{c}\text { Shape } \\
\text { index }\end{array}$ & $\begin{array}{c}\text { Specific gravity } \\
\left(\mathrm{kg} \mathrm{cm}^{-3}\right)\end{array}$ \\
\cline { 2 - 8 } & $n$ & Median & $\bar{X} \pm S_{\bar{x}}$ & $\bar{X} \pm S_{\bar{x}}$ & $\bar{X} \pm S_{\bar{x}}$ & $\bar{X} \pm S_{\bar{x}}$ & $\bar{X} \pm S_{\bar{x}}$ \\
\hline Free-Range & 160 & 90 & $61.907 \pm 0.549$ & $2.858 \pm 0.095$ & $0.377 \pm 0.002$ & $78.792 \pm 0.344$ & $1.085 \pm 0.0005$ \\
Deep-Litter & 160 & 90 & $61.358 \pm 0.655$ & $2.813 \pm 0.108$ & $0.378 \pm 0.003$ & $78.425 \pm 0.326$ & $1.086 \pm 0.0006$ \\
\hline $\mathrm{P}$ & & 0.337 & 0.522 & 0.754 & 0.722 & 0.457 & 0.330 \\
\hline
\end{tabular}

Tarım Bilimleri Dergisi - Journal of Agricultural Sciences

25 (2019) 181-188 
Table 2- Internal quality characteristics of eggs

\begin{tabular}{lcccccc}
\hline \multirow{2}{*}{ Groups } & & Yolk color & Albumen index & Haugh unit & Yolk index & $\begin{array}{c}\text { Meat-blood } \\
\text { spot range (\%) }\end{array}$ \\
\cline { 2 - 7 } & $n$ & Median & $\bar{X} \pm S_{\bar{x}}$ & $\bar{X} \pm S_{\bar{x}}$ & $\bar{X} \pm S_{\bar{x}}$ & - \\
\hline Free-Range & 160 & 13 & $11.313 \pm 0.225$ & $91.056 \pm 0.720$ & $49.074 \pm 0.255$ & $47.570 \pm 3.680$ \\
Deep-Litter & 160 & 13 & $10.696 \pm 0.278$ & $89.092 \pm 0.992$ & $48.124 \pm 0.338$ & $40.770 \pm 4.330$ \\
\hline $\mathrm{P}$ & & 0.898 & 0.083 & 0.101 & $0.023 *$ & 0.234 \\
\hline
\end{tabular}

material composition of the eggs produced. These differences can be attributed to the fact that 1) hens reared in free-range system are more dynamic compared to those reared in deep litter system,
2) hens reared in free-range system are exposed to direct sunlight and 3) hens reared in free-range system have access to reach other food sources including green grass.

Table 3- Findings related to chemical analysis of eggs

\begin{tabular}{|c|c|c|c|c|}
\hline Chemical analysis & Unit & Free-range systems & Deep-litter systems & Pvalue \\
\hline Gross energy & Kcal $100 \mathrm{~g}^{-1}$ & $133.00 \pm 3.840$ & $130.00 \pm 3.750$ & 0.606 \\
\hline Moisture & $\mathrm{g} 100 \mathrm{~g}^{-1}$ & $76.73 \pm 2.220$ & $78.23 \pm 2.260$ & 0.660 \\
\hline Ash & $\mathrm{g} 100 \mathrm{~g}^{-1}$ & $0.88 \pm 0.0250$ & $0.86 \pm 0.024$ & 0.603 \\
\hline Crude protein & $\mathrm{g} 100 \mathrm{~g}^{-1}$ & $12.19 \pm 0.352$ & $11.50 \pm 0.332$ & 0.227 \\
\hline Carbohydrate & g $100 \mathrm{~g}^{-1}$ & $1.53 \pm 0.044$ & $0.09 \pm 0.002$ & 0.000 \\
\hline Lipid & $\mathrm{g} 100 \mathrm{~g}^{-1}$ & $8.67 \pm 0.250$ & $9.32 \pm 0.269$ & 0.152 \\
\hline Cholesterol & $\mathrm{mg} 100 \mathrm{~g}^{-1}$ & $457.16 \pm 13.200$ & $503.69 \pm 14.500$ & 0.077 \\
\hline L-Alanine & $\mathrm{mg} 100 \mathrm{~g}^{-1}$ & $450 \pm 13.000$ & $396 \pm 11.400$ & 0.036 \\
\hline Glycine & $\mathrm{mg} 100 \mathrm{~g}^{-1}$ & $499 \pm 14.400$ & $464 \pm 13.400$ & 0.150 \\
\hline L-Valine & $\mathrm{mg} 100 \mathrm{~g}^{-1}$ & $900 \pm 26.000$ & $750 \pm 21.700$ & 0.011 \\
\hline L-Leucine & $\operatorname{mg} 100 \mathrm{~g}^{-1}$ & $1142 \pm 33.000$ & $932 \pm 26.900$ & 0.008 \\
\hline L-Isoleucine & $\mathrm{mg} 100 \mathrm{~g}^{-1}$ & $733 \pm 21.200$ & $593 \pm 17.100$ & 0.007 \\
\hline L-Threonine & $\mathrm{mg} 100 \mathrm{~g}^{-1}$ & $620 \pm 17.900$ & $812 \pm 23.400$ & 0.003 \\
\hline L-Serine & $\operatorname{mg} 100 \mathrm{~g}^{-1}$ & $771 \pm 22.300$ & $1006 \pm 29.000$ & 0.003 \\
\hline L-Proline & $\mathrm{mg} 100 \mathrm{~g}^{-1}$ & $590 \pm 17.000$ & $458 \pm 13.200$ & 0.004 \\
\hline L-Arginine & $\mathrm{mg} 100 \mathrm{~g}^{-1}$ & $176 \pm 5.080$ & $524 \pm 15.100$ & 0.000 \\
\hline L-Aspartic acid & $\operatorname{mg} 100 \mathrm{~g}^{-1}$ & $289 \pm 8.340$ & $861 \pm 24.900$ & 0.000 \\
\hline L-Methionine & $\mathrm{mg} 100 \mathrm{~g}^{-1}$ & $510 \pm 14.700$ & $462 \pm 13.300$ & 0.073 \\
\hline L-Glutamic acid & $\mathrm{mg} 100 \mathrm{~g}^{-1}$ & $782 \pm 22.600$ & $1529 \pm 44.100$ & 0.000 \\
\hline L-Phenylalanine & $\operatorname{mg} 100 \mathrm{~g}^{-1}$ & $780 \pm 22.500$ & $634 \pm 18.300$ & 0.007 \\
\hline L-Lysine & $\mathrm{mg} 100 \mathrm{~g}^{-1}$ & $683 \pm 19.700$ & $1223 \pm 35.300$ & 0.000 \\
\hline L-Histidine & $\operatorname{mg} 100 \mathrm{~g}^{-1}$ & $182 \pm 5.250$ & $293 \pm 8.460$ & 0.000 \\
\hline L-Tyrosine & $\operatorname{mg} 100 \mathrm{~g}^{-1}$ & $543 \pm 15.700$ & $491 \pm 14.200$ & 0.070 \\
\hline Se (Selenium) & $\mathrm{mg} 100 \mathrm{~g}^{-1}$ & $0.281 \pm 0.008$ & $0.406 \pm 0.012$ & 0.001 \\
\hline Vitamin $B_{5}$ (Pantothenic acid) & $\mathrm{mg} 100 \mathrm{~g}^{-1}$ & $2.53 \pm 0.073$ & $2.52 \pm 0.072$ & 0.927 \\
\hline Vitamin $\mathrm{B}_{7}^{5}$ (Biotin) & $\mu \mathrm{g} 100 \mathrm{~g}^{-1}$ & $27 \pm 0.780$ & $3.60 \pm 0.100$ & 0.000 \\
\hline Omega- 6 fatty acids & $\mathrm{g} 100 \mathrm{~g}^{-1}$ & $2.38 \pm 0.069$ & $2.29 \pm 0.066$ & 0.396 \\
\hline Omega-3 fatty acids & $\mathrm{g} 100 \mathrm{~g}^{-1}$ & $0.14 \pm 0.004$ & $0.13 \pm 0.003$ & 0.144 \\
\hline Vitamin $\mathrm{K}_{2}$ & $\mathrm{mg} 100 \mathrm{~g}^{-1}$ & $9.69 \pm 0.28$ & $11.16 \pm 0.320$ & 0.026 \\
\hline Vitamin $\mathrm{D}_{3}^{2}$ (Cholecalciferol) & $\mu \mathrm{g} 100 \mathrm{~g}^{-1}$ & $2.20 \pm 0.063$ & $0.93 \pm 0.0260$ & 0.000 \\
\hline VitaminA (Retinol,beta carotene) & $\mu \mathrm{g} 100 \mathrm{~g}^{-1}$ & $81.46 \pm 2.35$ & $133.5 \pm 3.850$ & 0.000 \\
\hline VitaminB $_{12}($ Cyanocobalamin) & $\mu \mathrm{g} 100 \mathrm{~g}^{-1}$ & $0.75 \pm 0.022$ & $0.78 \pm 0.023$ & 0.391 \\
\hline Vitamin E (Alfa tocoferol) & $\mathrm{mg} 100 \mathrm{~g}^{-1}$ & $2.10 \pm 0.061$ & $5.51 \pm 0.160$ & 0.000 \\
\hline Vitamin B (Thiamin) & $\mathrm{mg} 100 \mathrm{~g}^{-1}$ & $0.074 \pm 0.002$ & $0.060 \pm 0.002$ & 0.007 \\
\hline Vitamin $\mathrm{B}_{2}$ (Riboflavin) & $\mathrm{mg} 100 \mathrm{~g}^{-1}$ & $0.29 \pm 0.008$ & $0.26 \pm 0.007$ & 0.056 \\
\hline Vitamin $\mathrm{B}_{6}^{2}$ & $\mathrm{mg} 100 \mathrm{~g}^{-1}$ & $0.100 \pm 0.003$ & $0.070 \pm 0.002$ & 0.001 \\
\hline Folic acid ${ }^{6}$ & $\mu \mathrm{g} 100 \mathrm{~g}^{-1}$ & $28 \pm 0.810$ & $31 \pm 0.900$ & 0.068 \\
\hline Niacin & $\mathrm{mg} 100 \mathrm{~g}^{-1}$ & $0.067 \pm 0.002$ & $0.067 \pm 0.003$ & 1.000 \\
\hline
\end{tabular}


Breaking strength was not affected by the housing systems. While this finding shows similarity to those reported by Angelovičová et al (2014) and Clerici et al (2006), it contradicts with findings reported by Torges \& Matthes (1975), Krawczyk \& Calik (2006), Hidalgo et al (2008), Krowczyk \& Gornowicz (2010). These differences may be due to genotype and breeding conditions.

In this study, it has been determined that the housing systems do not affect egg weight. However, Doley et al (2010) have found that egg weight is higher in deep-litter system, and Pavlovski et al (1992) have pointed out that egg weights differ in cage, deep-litter and free-range systems. Lewko \& Gornowicz (2011) have found that egg weight is higher cage than litter and free-range systems. In another study, eggs in free-range system have been found to be heavier than those in cage system (Senčic \& Butko 2006), whereas Torges \& Matthes (1975), Pavlovski et al (2004), Clerici et al (2006), Samiullah et al (2014) and Wegner (1982) have reported that eggs produced in free-range system are lighter that those produced in cage system. These discrepancies in different studies could arise from the fact that the free-range system have not reached a standard structure like the other systems, which result in egg production with different quality parameters.

In the present study, both housing systems did not affect egg shell thickness. This finding disagrees with the reports made by Pavlovski et al (2001), Senčic et al (2006), Angelovičová et al (2014), Yang et al (2014), and Krowczyk \& Gornowicz (2010). On the other hand, Samiullah et al (2014) that have reported Shell thickness of eggs obtained from hens reared through cage system are higher than those obtained from hens reared in free-range system. In the present study, similar results were obtained in terms of specific gravity. It is thought that, this is caused by the fact that the egg shell thicknesses in both systems were similar. Ozcelik (2002) reported that there is an important relationship between egg weight and specific gravity, shell weight, shell thickness, specific gravity and shell weight and shell thicknesses in quail eggs.
There is not a difference between the two housing systems in terms of egg shape index. This was an expected result because the egg shape is determined in the magnum section of the egg canal and genotype is more effective on this than environmental factors. This finding agree with those reported by Lewko \& Gornowicz (2011). However, Pavlovski et al (2004), Senčic et al (2006), Sekeroglu et al (2010) have reported that housing systems are effective on shape index.

No difference was found between the housing systems in terms of yolk color. However, this finding contradicts with Torges \& Matthes (1975), Torges et al (1976), Pavlovski et al (2001), Senčic et al (2006), Senčic \& Butko (2006), Lewko \& Gornowicz (2011), Galis et al (2012) who reported that housing systems are effective on yolk color. This might be attributed to the fact that adequate amount of color pigments (Xanthophylls and Canthaxanthin) were included in the feed used for both systems in the present study. In case that the feed given to hens is poor in these substances, it is an expected outcome that the yolks of the eggs fed with additional green grass is yellower.

In the present study, the housing systems showed similarity in terms of albumen index and haugh unit. This agrees with the findings of Senčic et al (2006) who reported that eggs produced using hens reared in cage and free-range systems show similar characteristics in terms of albumen index and haugh unit. In a similar study, Samiullah et al (2004) have reported that albumen height and haugh unit are higher in cage systems compared to freerange system. In a study comparing eggs produced through cage, aviary and free-range systems, the best albumen quality was reached in eggs produced with free-range systems Pavlovski et al (2001). Pavlovski et al (2004) stated that haugh unit is lower in eggs produced through deep litter system when eggs produced through cage and free-range systems are compared. Dikmen et al (2017) have reported that eggs in the free-range system were better quality than eggs from convencional-cage and enriched-cage systems. Lewko \& Gornowicz (2011) 
stated that was not differences in terms of haugh unit among litter, cage and free-range housing systems.

Eggs produced through free-range systems have a higher value in terms of yolk index compared to those produced through deep litter system. This might be due to the lower moisture leve of eggs produced through free-range system. No literature has been found on the effects of housing systems on yolk index. In their study comparing eggs produced through cage and free-range systems, Senčic et al (2006) reported that there is no difference in terms of yolk index.

It was found that the housing systems did not have an effect on meat and blood spots. However, it was observed that the proportions of meat and blood spots were rather high in both systems. Both genetic factors and environmental factors are effective on meat and blood spots. Hence, pointing out that heredity and other environmental factors are effective on the formation of meat and blood spots. Lerner et al (1951) have reported that the degree of heredity is approximately 0.5 . In the literature, adequate information has not been found on the effects of housing systems on meat and blood spots.

Antioxidants such as vitamin A and vitamin $\mathrm{E}$ have been found to be lower in free-range hens because they find more opportunities for movement.

It was observed that the eggs produced by hens reared in free-range systems contain a higher level of vitamin $\mathrm{D}_{3}$. This is attributed to the fact that hens are exposed to direct sunlight in this system. This vitamin is known to be effective especially on bone development and human psychology.

It was determined that eggs produced by hens reared in free-range system had a higher value in terms of vitamin $\mathrm{B}_{7}$ (Biotin). In addition to taking part in oil, protein and carbohydrate metabolisms as a coenzyme, Biotin also plays important role on bone marrow and nerve tissues, hair and nails.

It was observed that there was no significant difference between the free-range and deep litter system in terms of cholesterol. Similar result was also observed by Torges et al (1976) who pointed out that there is no difference between eggs produced through free-range, deep litter and cage systems in terms of total cholesterol. Nistor et al (2014) have reported that the protein ratio is $10.35 \%, 9.97 \%$; dry matter content is $23.37 \%, 22.96 \%$ and the oil ratio in yolks is higher in eggs produced through conventional cage system than free-range eggs, respectively. Radu-Rusu et al (2014) have reported

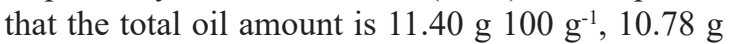
$100 \mathrm{~g} \mathrm{~g}^{-1}$, cholesterol amount is $211 \mathrm{mg}^{-10 \mathrm{~g}^{-1}, 202}$ $\mathrm{mg} 60 \mathrm{~g}^{-1}$, total energy amount is $0.36 \mathrm{MJ} \mathrm{egg}^{-1}$ and $0.35 \mathrm{MJ} \mathrm{egg}^{-1}$ for eggs produced through cage and free-range systems, respectively. Galis et al (2012) have reported in a study comparing eggs produced through organic, free-range, aviary and cage systems that the protein and water ratio is highest in free range system eggs, ash ratio is lowest in cage system eggs and highest in organic system eggs.

It has been determined in this study that valine, leucine, isoleucine, methionine and phenylalanine are rich in the free-system and lysine and threonine are rich in the deep-litter system which are essential for humans. Other amino acids contents were similar in free-range and deep-litter systems. Küçüky1lmaz et al (2012) have reported that eggs produced in the organic system were poor in yolk omega-3 content when compared to eggs laid by hens reared in the conventional system.

\section{Conclusions}

In this present study, it was determined that the freerange and deep litter systems are effective on egg quality characteristics. The aminoacid compositions of eggs are significantly affected by the housing systems; more importantly, eggs produced through free-range system were observed to be richer in essential amino acids, compared to deep litter systems. In general, since eggs produced through free-range system had more Vitamin $\mathrm{D}_{3}$, Vitamin 7 (Biotin) and less total cholesterol, they were determined to be higher in quality compared to deep litter system eggs. Thus, it has been concluded that preferring eggs produced trough free-range systems would be important for human health, especially in regions where humans expose to less sunlight. 


\section{Acknowledgements}

We would like to express our thanks to the Scientific Researches Project Coordination Department of Ordu University for their support of AR-1530 project number this study.

\section{References}

Altan Ö (2015). Yumurta Oluşumu, Kalitesi ve Biyoaktif Komponentleri. Ege Üniversitesi Basımevi, Bornova, İzmir ISBN:978-605-84400-0-5

Anderson K E (2009). Overview of natural and organic production: Looking back to the future. Journal of Applied Poultry Research 18: 348-354

Angelovičová M, Ševčíková V, Angelovič M \& Bučko O (2014). Comparison of two different breeding systems of laying hens in relation to egg shell quality. Animal Science Biotechnology 47(2): 166-171

Anonymous (2010). Minitab, version 16. Minitab Inc., State College, PA

Clerici F, Casiraghi E, Hidalgo A \& Rossi M (2006). Evaluation of eggshell quality characteristics in relation to the housing system of laying hens. EPC 2006 - 12 $2^{\text {th }}$ European Poultry Conference, 10-14 September, Verona, Italy, pp. 277

Dikmen B Y, İpek A, Şahan Ü, Sözcü A \& Baycan S C (2017). Impacat of different housing systems and age of layers on egg quality characteristics. Turkish Journal of Veterinary and Animal Science 41: 77-84

Doley S, Barua N \& Kalita N (2010). Effect of rearing systems on meat and egg qualities in indigenous fowls. Indian Veterinary Journal 87: 168-170

Galis A M, Van I \& Théwis A (2012). Organoleptic, chemical and microbiological quality of table eggs obtained in different exploitation systems for laying hens in Romania. Scientific Paper, Series D, Animal Science 55: 162-166

Hanusová E, Hrnčár C, Hanus A \& Oravcová M (2015). Effect of breed on some parameters of egg quality in laying hens. Acta Fytotechnica et Zootechnica 18: 2024

Haugh R (1937). The Haugh unit for measuring egg quality. US Egg Poultry Magazine 43: 552-555

Hidalgo A, Rossi M, Clerici F \& Ratti S (2008). A market study on the quality characteristics of eggs from different housing systems. Journal of Food Chemistry 106: $1031-1038$
Krawczyk J \& Calik J (2006). Quality of table eggs from hens of conservation breeds kept in confinement or on free range. Polish Journal of Natural Science 3: 433-438

Krawczyk J \& Gornowicz E (2010). Quality of eggs from hens kept in two different free-range systems in comparison with a barn system. Archiv für Geflügelkunde 74: 151-157

Küçükyılmaz K, Bozkurt M, Herken E N, Çınar M, Çatlı A U, Bintaş E \& Çöven F (2012). Effect of rearing systems on performance, egg characteristics and immune response in two-layer hen genotype. AsianAustralian Journal of Animal Science 25(4): 559-568

Lerner I M, Taylor L W \& Lowry D C (1951). Selection for increased incidence of blood spots in white leghorns. Poultry Science 30: 748-757

Lewko L \& Gornowicz E (2011). Effect of housing system on egg quality in laying hens. Annal of Animal Science 11(4): 607-616

Leyendecker M, Hamann H, Hartung J, Kamphues J, Ring C, Glünder G, Ahlers C, Sander I, Neumann U \& Distl O (2001). Analysis of genotype-environment interactions between layer lines and hen housing systems for performance traits, egg quality and bone breaking strength. $2^{\text {nd }}$ communication: egg quality traits. Züchtungskunde 73: 308-323

Nistor L I, Albu A \& Usturoi M G (2014). Knowledge of chemical indicators of eggs from hens reared in conventional and free-range system. Food Science and Technology 71: 119-124

Nistor L I, Albu A, Nistor A C \& Usturoi M G (2015). Aspects of eggs quality provided from free range and conventional systems. Journal of Microbiology Biotechnology and Food Science 5: 186-189

NRC (1994). Nutrient Requirements of Poultry, Ninth Revised Edition, National Academy Pres, Washington D.C

Ozcelik M (2002). The phenotypic correlations among some external and internal quality characteristics in Japanese quail eggs. Veterinary Journal of Ankara University 49: 67-72

Pavlovski Z, Mašic B, Josipovic' S \& Hopic S (1992). The effect of the system of housing on the laying performance of hens in small flocks. Biotechnologija u Stočarstvu 8: 57-63

Pavlovski Z, Hopic' S \& Lukic M (2001). Housing systems for layers and egg quality. Biotechnology in Animal Husbandry 17: 197-201 
Pavlovski Z, Škrbic Z \& Lukic M (2004). Influence of housing type on internal and external quality of eggs in small flocks of hens. Živinarstvo 39: 9-23

Radu-Rusu R M, Usturoi M G, Leahu A, Amariei S, Radu-Rusu C G \& Vacaru-Opriş I (2014). Chemical features, cholesterol and energy content of table hen eggs from conventional and alternative farming systems. South African Journal of Animal Science 44: $3-42$

Samiullah S, Roberts J R \& Chousalkar K K (2014). Effect of production system and flock age on egg quality and total bacterial load in commercial laying hens. Journal of Applied Poultry Research 23: 59-70

Sekeroglu A, Sarica M, Demir E, Ulutas Z, Tilki M, Saatci M \& Omed H (2010). Effects of different housing systems on some performance traits and egg qualities of laying hens. Journal of Veterinary Advances 9: 1739-1744

Senčic Đ \& Butko D (2006). Productivity of layers and egg quality in free range and cage system of housing. Poljoprivreda 12: 48-51
Senčic Đ, Antunovic Z, Domac'inovic M, Šperanda M \& Steiner Z (2006). Egg quality from free range and cage system of keeping layers. Stočarstvo 60: 173179

Torges G \& Matthes S (1975). Investigations on the effect of type of management of laying hens (free-range, on the floor or in cages) on egg quality characters. Kleintierzucht in Forschung und Lehre Celler Jahrbuch 23: 18

Torges H G, Matthes S \& Harnisch S (1976). Comparative studies on eggs from commercial poultry farms with free-range, deep litter or cage management. Archiv fur Lebensmittel-hygiene 27: 107-112

Wegner R M (1982). Investigation of production systems for laying hens with regard to ethological aspects. Landbauforsch Volkunde 32: 162-166

Yang H M, Yang Z, Wang W, Wang Z Y, Sun H N, Ju X J \& Qi X M (2014). Effects of different housing systems on visceral organs, serum biochemical proportions, immune performance and egg quality of laying hens. European Poultry Science 78: DOI:10.1399/ eps. 2014.48 